\title{
Back to the Future: \\ The Arab Uprisings and state (re) formation in the Arab \\ World
}

\begin{abstract}
Adham Saouli*
This article contributes to debates that aim to go beyond the 'democratisation' and 'post-democratisation' paradigms to understand change and continuity in Arab politics. In tune with calls to focus on the actualities of political dynamics, the article shows that the literatures on State Formation and Contentious Politics provide useful theoretical tools to understand change/continuity in Arab politics. It does so by examining the impact of the latest Arab Uprisings on state formation trajectories in Iraq and Syria. The Uprisings have aggravated a process of regime erosionwhich originated in post-colonial state-building attempts-by mobilising sectarian and ethnic identities and exposing the counties to geo-political rivalries and intervention, giving rise to trans-border movements, such as ISIS. The resulting state fragmentation has obstructed democratic transition in Syria and constrained its consolidation in Iraq.
\end{abstract}

Keywords: state formation; democratisation; contentious politics; Arab Uprisings; Iraq; Syria; ISIS.

This study examines the impact of the Arab uprisings on state formation in the Arab world, with emphasis on Iraq and Syria. I argue that the uprisings have exacerbated a process of state fragmentation, which has roots in long-term state-building processes in the postcolonial era. In this process, the ability of regimes to monopolise power domestically was eroding and the states' immunity against external penetration was waning. In Syria and Iraq, the uprisings had two direct impacts. First, they accelerated sectarian and ethnic mobilisation, which was latent under the ideological hegemony of Arab nationalism, but had gradually became salient, especially after the fall of Saddam Hussein in 2003 and the uprising in Syria in 2011. This not only sharply increased longstanding challenges to the monopoly of power by ruling regimes, but also has contributed to state disintegration and blocked attempts to reform their political systems. Secondly, they accentuated Iraq and Syria's vulnerability to external penetration by rival regional powers, making state reformation even more difficult.

The article is divided into two main sections. Theoretically, I argue that an understanding of political change and continuity in the Arab world requires moving

\footnotetext{
${ }^{*}$ I would like to thank Francesco Cavatorta, Raymond Hinnebusch, and an anonymous reviewer for their very useful comments and suggestions on previous versions. I am responsible for any remaining flaws.
} 
beyond the 'democratization' and 'post-democratization' frameworks. Following on calls to refocus scholarly attention on the actualities of political dynamics, in the first section, I argue that an examination of state formation and the contentious politics that punctuate this process provide useful avenues to understand political change and continuity in the Arab world. Bringing in the state formation literature provides historical depth to current political upheavals in the Middle East, such as the Arab uprisings. In focusing on trajectories of state formation in varying contexts, we examine how state-building attempts engender anti-regime political mobilisation, creating contentious politics. Contentious politics activate latent identities, mobilise passive populations, and give rise to new ideologies and actors, creating opportunities for political change, of which democratisation is only one possibility. Whilst I argue that an understanding of the socio-political conditions that could facilitate or obstruct democratisation is socially important, we should not allow this to determine or distort our analysis of politics in the region.

In the second section I present an empirical analysis on the impact of the Arab uprisings on Iraqi and Syrian state formation. First, I analyse how the post-colonial state-building processes in Iraq and Syria contributed to regime erosion. This will set the historical context to then examine the impact of the current uprisings on each of the two cases. I conclude the study by assessing the conditions that could facilitate or hinder democratisation in Iraq and Syria.

\section{Political change, continuity and development in the Arab world}

Before and beyond democratization and authoritarian resilience

Attempts to understand political change and continuity in the Middle East have centred on two intersecting questions: First, how do we explain the absence of democracy in the Arab world? Second, how do we explain regime resilience in the region? Whilst the answer to the latter question should provide insights to the former, the two waves of literatures that contributed frameworks to answers these questions remained analytically divorced. The first, which emerged in the 1990s, focused on Arab states' resistance to the 'third wave' democratisations, continuing a legacy initiated by modernisation theories of the 1950s and 1960s. ${ }^{1}$ The absences of a civil society, a strong bourgeoisie, democratic political culture or democratic interlocutors were all advanced as explanations for the absence of democracy in the region ${ }^{2}$. However, disenchanted by 
the faltering hope of political change in the region scholars moved to a 'postdemocratisation' paradigm that examined 'how political rule in the Arab countries is effectuated, organized, and executed' to generate stability and regime survival. ${ }^{3}$

Then came the Arab uprisings in 2010/11. Two ostensibly entrenched authoritarian leaders (Bin Ali of Tunisia and Mubarak of Egypt) were toppled in a matter of few weeks, triggering a wave of uprisings in other Arab countries. Academic responses to the uprisings reflected the two dominating paradigms. Some regional experts argued that a focus on the 'myth of authoritarian stability' had missed the underlying factors that caused the winds of change. ${ }^{4}$ However, with the return of the military to power in Egyptian politics, emergence of civil wars in Syria, Libya, Iraq, and Yemen, constrained transition in Tunisia, and regime survival in Morocco, Jordan and the Gulf, others observed continuities in Arab politics ${ }^{5}$.

Nevertheless, despite the greater pace, intensity, and innovations in political protest, the latest uprisings do not represent a total break with previous forms of political contention in the Arab world. For example in 2005, Beirut was engulfed by Midan al-Tahrir-like protests, framed as a "Cedar Revolution" after the assassination of Lebanon's Prime Minister Rafic Hariri. The ousting of Muammar al-Qaddafi in 2011-a combination of accumulated domestic opposition and external military intervention-is, to a degree, similar to the ousting of Saddam Hussein in 2003. In Egypt, the toppling of Mubarak in 2011, which paved the way for the election of the Muslim Brotherhood, which in turn led to a deep political polarisation in Egypt providing the opportunity for the military to return to the political arena, is comparable to the elections of the Islamists in Algeria; there the refusal of the army to surrender to the ballot boxes triggered a civil war of the 1990s. A comparison between the current civil war in Syria and the Baathist-Muslim Brotherhood bloody struggle of 1978-82 reveals similar processes, albeit with different outcomes. In each case the main political contention was between entrenched and ostensibly secular regimes and an Islamist opposition.

Hence, it should not come as a surprise that scholarly responses to the uprisings have fluctuated between explanations of change and continuity. However, the analytical link between political change and continuity in Arab politics remains to be established. One reason for the absence of such an analytical link is the democracy factor. This factor has framed and in some cases determined how we think about political change in the Arab world. In searching for the "absence of democracy", scholarly attention has been 
diverted away from developing methods, concepts and theories to understand how politics actually works. ${ }^{6}$ The call for a 'post-democratisation' paradigm may have contributed to bring politics back in to the analysis; however, its focus on regime resilience comes at the expense of missing interesting forms of resistance against domination, and hence an understandings of potential originators of change ${ }^{7}$. An examination of the 'genealogy of resistance's, for example the politicisation, rise, and development of Shi'a political Islam in opposition to Baathist domination in Iraq, could be very useful to understand and explain strategies of regime adaptation, state reformation or political change in contemporary Iraq.

Moving beyond the democratisation and post-democratisation requires the settling of two issues. First, there is a need to move one step back to analyse politics as a domain of domination and resistance that, especially in the Arab world, takes place in processes of state making and unmaking in varying political contexts. ${ }^{9}$ This involves a 'return to the classic question about what politics is and what are the relevant political fields and actors' 10 .

Second, it is important to free political analysis from normative frames, while recognizing that normative concerns continue to shape societies' interests in the political world. Political analysis cannot be indifferent to many Arabs' resistance to the violence, injustice, and corruption of authoritarianism, ${ }^{11}$ and understanding its causes and the conditions for democratic transition are socially important-not only for a Western audience of American political science, donors or policymakers ${ }^{12}$. But answers to this normative goal would first require an understanding of the political world.

\section{Bringing politics back in: State formation and Contentious Politics}

In this section, I will argue that a focus on state formation/deformation processes and the contentious politics they generate offers two main advantages in understanding political change in the Arab world. First, it contributes to the identification of the underlying struggles that gives politics its shape and direction: despite the varying paths to state formation, the direction of the process is universally similar: a drive to centralise (especially coercive) power as a pre-requisite to institutionalise order and to facilitate socio-economic development. Second, this drive almost always generates resistance by dissatisfied challengers, spawning contentious politics. I start by sketching the state formation process. 
The collapse of the Ottoman Empire led to the emergence of political boundaries (initially envisioned as European spheres of influence). Unlike European state formation processes, boundaries in the Arab world came before states and constituted the social environments within which states could form, deform, or develop. State formation pits regimes against their challengers in struggles aiming to dominate three analytically separate but interrelated domains of social life: the coercive, ideological, and the socioeconomic. ${ }^{13}$

By monopolising coercion (control over the tools of violence such as the police, security, army, courts) an actor prevents its rivals from similar tools of violence that would otherwise threaten it. Starting in the 1950s in republics such as Egypt, Iraq, Syria, Yemen or Libya, we observe a varying but steady process of increasing domination by the army over political life, usually at the expense of other social and political forces. ${ }^{14}$ In monarchical regimes, such as Jordan or Saudi Arabia, royal families directly monopolised coercion. Secondly, depending on the cultural composition of a society, regimes articulated relevant ideologies to legitimise their rule and dominate the ideological sphere. In Saudi Arabia, King Abdel Aziz used a Wahhabi interpretation of Islam to help overcome tribal and regional divisions in the nascent kingdom; it then became the state ideology. Populist regimes (Egypt, Iraq, Syria, Yemen) of the 1950s and 1960s championed ideas of Arab Nationalism, socialism, anti-colonialism and national independence, de-legitimising the rule of their predecessors and repressing competing frameworks, such as Islamism. The Arab uprisings have shown that the ideological sphere continues to be an area of contention among Islamists, nationalists, and, increasingly, sub-state sectarian communities. Finally, controlling the economic sphere was essential to state formation. Whilst tax-collection in European state formation was crucial for kings to wage war and suppress internal rivals ${ }^{15}$, in the Middle East rent from natural resources or external patrons has been essential to augment the co-optative power of regimes in oil-rich monarchies or strategically located states, such as Jordan. In populist republics of the 1950s and the 1960s, redistribution from state-led development (agrarian reform, industrialisation, import-substitution) became comparable vehicles for co-optation needed for regime survival.

Successful domination over the coercive, economic, and ideological spheres gave rise to political regimes ${ }^{16}$ of varying types. But these were far from consolidated 'states', understood here as institutions (set of norms, rules and practices) that regulate but 
stand above political struggles and actors. In early state formation, a regime is one dominant group ruling over others in a particular jurisdiction. As Max Weber argues: 'Like the political institutions historically preceding it the state is a relation of men dominating men, a relation supported by means of legitimate (i.e. considered to be legitimate) violence. ${ }^{17}$ While a certain co-optation of social forces in rentier monarchies and populist republics was necessary for regime survival, ${ }^{18}$ this was far from being fully politically inclusive--as facilitated by competitive elections allowing participation by all social forces. The limits of inclusion made the Arab state vulnerable, not only to political shocks (such as the Arab uprisings) but also to external infiltration. ${ }^{19}$ The drive for regime survival engenders resistance against such attempted domination. Resistance forces seek to de-monopolise a regime's grip over the above-mentioned three spheres; by offering competing ideologies, economic strategies, and, in certain cases, armed resistance, oppositional forces create the basis for alternative regimes.

Whilst state formation provides a generic framework that highlights a regime's drive for domination and an opposition's resistance, this struggle is punctuated by periods of what students of social movements call Contentious Politics (CP):

episodic, public, collective interaction among makers of claims and their objects when (a) at least one government is a claimant, an object of claims, or a party to the claims and (b) the claims would, if realized, affect the interests of a least one of the claimants. ${ }^{20}$

The CP research agenda raises key questions and provides interesting conceptual tools to understand political change, continuity and democratisation in the Arab world: When and under what conditions do passive populations collectively mobilise for change? How and why does an opportunity become visible for regime contenders? What kind of frames do the contenders construct as they struggle for power? What effects would this contention have on identity?

Departing from state formation and $\mathrm{CP}$, the latest Arab uprisings appear an episode of collective interaction that pitted previously passive populations against regimes under varying socio-political conditions. By presenting alternative sociopolitical visions (democracy, Islamism, freedom, pluralism), contenders challenged the incumbent regimes' monopoly over the ideological sphere, whilst attempting to engage and mobilise the latent public. ${ }^{21}$ For example, the Midan al-Tahrir Square collective action was a site of political protest that challenged Mubarak's monopoly over the 
national narrative, whilst seeking to mobilise the public for change; it did so by imagining and promising an alternative society. ${ }^{22}$

The uprisings opened an opportunity for change, but whether the opportunity would be realised or not is a different question. What contenders perceive as an opportunity, which is 'an activating mechanism responsible in part for the mobilization of previously inert populations' 23 , regimes and their supporters perceive as a threat. To delegitimise antagonists, regimes engage in framing processes, accusing the latter of being "terrorists", "agents of foreign states" or "instigators of instability". In heterogeneous societies, such as Iraq or Syria, interactive framings can activate or aggravate identity divides; this occurs when 'political entrepreneurs draw together credible stories from available cultural materials, similarly create we-they boundaries, activate both stories and boundaries as a function of current political circumstances, and manoeuvre to suppress competing models'.24

Contentious politics also involves collective violent campaigns that defy a regime's capacity to monopolise coercion. When this occurs, it provides the space for contenders to establish new forms of authority: establish order (monopolising coercion in "liberated areas"), institutionalise courts, capture sites of economic significance, raise new flags, and protect the 'boundaries' of the areas they occupy. Regime's and "counterregimes" engage in rival projects of state formation. ${ }^{25}$ Contentious politics, however, need not always be about state (re-) formation; I analytically connect state formation to $\mathrm{CP}$ because most Arab states remain prone to reconstruction, and contentious politics are integral to this process. The Arab uprisings are an episode of intense struggle between regimes and their contenders; but the quantitative change in intensity of the struggle, its visibility, and the emergence of new actors, claims and forms of political mobilisation should not conceal the qualitative continuity of the struggle from the preUprising period.

But what does the examination of state formation and contentious politics imply for the democratization debate? Contentious politics, which in the Arab world is directly linked to state formation/reformation, is a necessary but not sufficient condition for democratization. Necessary because contentious politics reflect periods of intense struggles between regimes and their rivals, juxtaposing opposing socio-political claims, and generating conditions for political change, including democratization. However, as the cases of Syria and Iraq will illustrate, there are several variables that can intervene 
between contentious politics and democratization. Such variables include, but need not be limited to, sectarian and ethnic fragmentation, the internalization of external geopolitical rivalry, and collective violence, which not only constrain democratization but also threaten to fragment the state as a territorial entity.

\section{Back to the Future: the Arab Uprisings and State (re) formation in Iraq and Syria}

State-building and regime erosion in Iraq (1968-2003) and Syria (1963-2011)

The state formation process in Iraq and Syria—the attempt by Arab nationalist regimes to attain political independence, socio-economic development, and nation-buildingsince the 1960s fomented the seeds of regime erosion, returning these states to square one of state formation half-a-century later ${ }^{26}$. Regime erosion can be attributed to three interrelated trajectories that had varying effects on the two cases: (1) intra-regime and regime-opposition struggles for domination led to the monopolisation of power in the hands of a few and to mass political exclusion; (2) to reproduce their domination at the state level, regimes resorted to kinship ties, contributing-intentionally or unintentionally-to the activation and reproduction of identity divides within their societies, divides which political contenders utilised for political mobilisation; and (3) because of political exclusion and the activation of identity divides, regimes and the territorial states in which they dominate became more vulnerable to unanticipated shocks (such as the Arab uprisings) and external penetration, which aggravated regime erosion and state disintegration.

First, colonial divisions of the region and later colonial domination in Iraq and Syria gave rise to various political ideologies (Arab Nationalist, Baathist, Communist, Nationalist, Islamist), seeking liberation, economic development, and, for Arab Nationalists, Arab political union. These views reflected the socio-political grievances of the time, and contradicted the interests of the ruling elites. But the absence of democratic means that could channel these socio-political grievances transformed the military, which began to be infiltrated by these ideologies, into a vehicle of political change. Whilst the military began to infiltrate the political realm as early as 1936 in Iraq and 1949 in Syria, two military coups in 1958 (Iraq) and 1963 (Syria) would trigger state formation processes and have lasting effects on both countries. The coups, which brought coalitions of revolutionary forces to power, initiated an intra-coalition elimination contest: first between Baathists and their Arab Nationalist, Communist and 
nationalist foes; and second, among the Baathists when they reached power in Iraq (1968) and Syria (1963). The elimination contests among Baathists culminated in the emergence of the narrowly based regimes of Saddam Hussein in Iraq (indirectly since 1968 and directly since 1979) and Hafez Assad in Syria (1970). In these processes, political foes were purged, detained and killed, laying the foundations of authoritarian regimes where the monopoly over the use of violence determined the patterns of other social, economic and judicial spheres ${ }^{27}$.

To maintain a monopoly over coercion, Assad and Hussein designed in-built protection against military coups by diversifying military, security and intelligence agencies and creating paramilitaries. The monopoly over coercion facilitated the domination of the ideological level; Baathist ideology, as interpreted by the wielders of coercive power, became the state ideology: first through the 'Baathification' of the military and then of society through education, party socialisation, and the media. Alternative ideologies were excluded or suppressed. At socio-economic levels, both regimes attempted, either through agrarian reforms (Syria) or through oil rent (Iraq), to include previously marginal social forces in state-driven developments. Departing from his predecessor's socialist and minoritarian regime, Assad also integrated members of Sunni bourgeoisie from Damascus and Aleppo, giving them important political posts in the party and government; he, however, maintained a monopoly over security, military and foreign policy decisions. ${ }^{28}$

In both cases, political exclusion had adverse effects on state-building; the political system did not offer opportunities for accountability, especially of regime figures whose presence was crucial for regime survival. ${ }^{29}$ As such, political exclusion eroded regimes' socio-political ties with society. Whilst both regimes did not lose total support, political exclusion and repression and elite corruption eroded their legitimacy, and formed the basis for political mobilisation when opportunities emerge (such as the 1978-82 Islamic rebellion in Syria or such as the 1991 uprising in Iraq).

Second, ideological and personal rivalries within the Baath party, coupled with the struggle to monopolise coercive power, gave rise to the issue of political trust. In both cases, Baathist ideology and the political party ceased to form the political cement required to tie regimes together. Ideological erosion was countered by a reactivation of tribal and sectarian ties. Each regime attempted to install kin in key positions of party and state-in particular its coercive agencies. Under Saddam Hussein, the process starts 
with the 'Tikitization' of the Baath in the early 1970s and culminates in direct family rule by the late $1990 \mathrm{~s}^{30}$ In Syria, the intra-regime struggles among Baathists began to take a sectarian dimension when Salah Jadid purged first several Sunni officers and then Ismaili and Druze comrades. In the last round, Assad and Jadid remained as the last Alawi Baathist leaders, before Assad's 'Corrective Revolution' overthrew Jadid. Under Assad, key security, intelligence, and military posts were primarily allocated to trusted Alawi officers. ${ }^{31}$

On implication of this process is that it exacerbated the regimes' alienation in society, eroding further its legitimacy. In Iraq, the Baathification and Tikritisation of the state not only alienated contenders within the Sunni community, but also gradually contributed to the demarcation of sectarian-Sunni-Shi'a-cleavages and exacerbated ethnic-Arab-Kurdish-boundaries. Fearing a Shi'a rebellion in the 1970s, Saddam Hussein initiated a repressive campaign against all expressions of Shi'a religious and political contention, reinforcing Shi'a perception of marginalisation. But the activation of sectarian boundaries is not a one-way road, generated only by regime actions; in Iraq it was also generated by the increasing political consciousness of Iraqi Shi'as. The emergence of the Islamist Dawa Party in 1958, which initially came as a response to the Communist ideological challenge, formed an early expression of this consciousness. By the late 1970s, the Dawa's ability to mobilise the Shi'as community against the Baath formed a significant threat to Saddam Hussein. ${ }^{32}$ The identity divides separating the Iraqi Arabs from the Kurds started earlier and was aggravated by the failure of successive Iraqi regimes to accept Kurdish cultural and regional autonomy. ${ }^{33}$ In the 1990s Iraqi Kurds began to enjoy de facto autonomy before, as we shall see below, this became constitutional in 2005.

In Syria, Assad faced an Islamic rebellion culminating in civil war in 1978-1982. ${ }^{34}$ This civil war and the regime's attack on the Sunni bastion of Hama, which killed thousands, in 1982 reinforced sectarian divisions and perceptions within Syria, undermined the regime's secular ideology and gave regime contenders the opportunity to frame it as sectarian and Alawite. To be sure, the presence of heterogeneous society, made up of various sectarian and ethnic communities, as that of Iraq and Syria, does not in itself cause sectarian divisions, nor does it imply that the conflict is purely cultural; but a heterogeneous society provides the cultural material for political contenders to frame the conflict in cultural terms in order to mobilise support. The Islamists targeting 
of Alawite officers, as in the Aleppo's artillery school 1979, and the discourse employed, which framed the regime in sectarian terms, activated identity divides in this contentious episode. ${ }^{35}$ In this case-unlike after 2011-the sectarian cleavage was muted by the fact that the largely Sunni peasantry remained in the regime coalition, coopted by Ba'thist agrarian reforms ${ }^{36}$.

Thirdly, the combination of domestic political exclusion and identity divides exposed Iraq and Syria to external infiltration. The strategic location of both states, in the Arab-Israeli conflict region (Syria) and the heart of the Middle East (Iraq), has meant that domestic rivalries become integral to the regional (and international) balance of power. In the state formation process, the fear of external subversion exacerbated the drive to monopolise power domestically. ${ }^{37}$ Regimes and their contenders perceived regional developments as opportunities or threats to alter and maintain the domestic power balance. For example, the Syrian civil war in 1978-1982 cannot be divorced from Egypt's pressure on Assad after ties between the two states soured in the wake of the Camp David agreements. The Islamists perceived this as an opportunity to topple Assad; but it also increased the regime drive to maintain power. ${ }^{38}$

Similarly, the 1991 uprising in the southern provinces of Iraq came with the perception of (and promise made by the US to) the Shi'as of Iraq that Hussein's regime would be toppled. However, during that uprising, Hussein capitalised on the regional and international decision to keep him in power to crush the uprising. Saddam Hussein framed the uprisings as an Iranian conspiracy aiming to transform Iraq into an Islamic state. The repression of the uprising, however, ingrained sectarian and ethnic boundaries in the country. ${ }^{39}$

\section{The Arab Uprisings and state formation in Iraq and Syria, 2011-2014}

It is in the context of the state formation trajectories examined above that we can understand the impact of the uprisings on Iraq and Syria. In the eyes of the Syrian and Iraqi opposition groups, the 'Arab Spring' presented an opportunity to readdress the Iraqi balance of power, which emerged in 2003, and to reform or overthrow the Syrian regime. The effects of the uprisings on Iraq and Syria, however, vary.

When the uprisings erupted in 2010/11 Iraq had already established regime change and inaugurated a proto-democratic experiment. Contrary to the 1991 uprisings which failed to materialise in regime change, in 2003 the interests of the Iraqi 
opposition, especially Kurdish and Shi'a organisations, converged with the US's strategy to topple Saddam Hussein. The removal of Hussein from power paved the way for the Iraqi opposition to initiate a new political regime centred on the two main Kurdish movements, the Kurdish Democratic Party and Popular Union of Kurdistan, and Shi'a movements, al-Dawa, the Sadr Movement, the Supreme Islamic Council in Iraq, and, to a lesser extent, the Sunni Iraqi Islamic Party. A new constitution was ratified, satisfying the aspirations of the Kurdish movement, guaranteeing cultural and administrative autonomy and federal democracy in Iraq; the new order also brought the Shi'a to the heart of the political system, making them the dominant actor in the new state-building process. A series of largely fair national elections in January and December 2005 and 2010 consolidated the new political arrangement and demarcated the sectarian and ethnic political map of the country. ${ }^{40}$ What emerged, though not formally presented as such, was a form of consociational democracy, which, theoretically at least, accepted the presence of political, religious and ethnic communities. As in Lebanon, the apportionment of posts in the state aimed to represent and incorporate the main communities of the country: the Shi'as took the executive prime minister post, the presidency was given to the Kurds, and house speaker to the Sunnis.

But this state-building process was fraught with domestic and external problems. Domestically, not all Sunni factions accepted the new political order. In opposition to the US occupation, to increasing Iranian influence, and to Shi'a and Kurdish political dominance, many Sunnis, with some exceptions, refused to legitimise the new regime. ${ }^{41}$ Shi'a forces filled the main offices of the state and used state resources to augment their social bases and to blackmail and repress their political opponents. This increased Sunnis' perception of marginalisation. The US decision to dismantle the army and the 'De-Baathification' program left hundreds of thousands, of whom many were Sunnis, jobless. This further weakened regime legitimacy in Sunni governorates, especially Anbar and Salaheddine 42 .

Resistance to the new form of domination and the USA-led occupation began to turn both political and violent as early as 2004. Violent resistance targeted the rebuilding of security and military institutions, with concentrated attacks on recruitment centres, and the occupying forces. Sunni resistance provided the opportunity for former Baathists and Saddamists, Sunni tribal forces, and Islamists, especially al-Qaida related organisations, to capitalise on Sunni marginalisation to 
advance their political goals. ${ }^{43}$ This resistance, in turn, reinforced the Shi'a drive to monopolise power. The Shi'a's fear of a reversal of the state-building process and Sunni perception of marginalisation entrenched the Shi'a-Sunni divide.

The post-2003 Iraqi state-building process intersected with regional geopolitical rivalries. Syria, which aimed to destabilise and deter US control in Iraq, hosted former Baathists and facilitated the transfer of Islamist jihadists to Iraq ${ }^{44}$ For al-Qaida's Iraqi version, the Islamic State of Iraq (ISI)--the original version of the Islamic State of Iraq and Syria(ISIS)--Iraqi state failure provided opportunities to fight the US, the Shi'as, which were targeted by suicide bombers, and Iran, and to establish a "caliphate". Faced with the threat of regime change, Iraqi military and security forces in collaboration with Shi'a militias in turn sought to repress Sunni Islamist militants and cleanse Sunnis of certain areas of Baghdad, thereby, further marginalising the community. By 2007, Iraq was facing a sectarian civil war. For Sunnis, the new regime intended to repress them, impose a Shi'a-dominated system, and provide Iran with greater influence; thus, challenging Iraq's Arab identity. For Shi'as, many Sunnis are intent on reversing the nascent democratic system, paving the way for the return of the Baath and legitimising al-Qaida attacks on Shi'as. These mutual interpretations not only weakened the democratic experience in Iraq, but also eroded the capacity and legitimacy of the new regime in Sunni areas of Iraq.

It is against this background that the Arab uprisings began to impact Iraq in 2011. In 2011 the US withdrew most of its troops from Iraq. US occupation had, in varying degrees, constrained the behaviour of Iraqi political forces. However, American withdrawal juxtaposed Iraqi communities, with their varying visions of the country, against one another. In a drive to monopolise coercive power in the state, Prime Minister Nuri al-Maliki of the Dawa Party clashed with both Shi'a and Sunni militias; in his drive to centralise power he installed his own supporters in the state, including family members, overriding official institutions. ${ }^{45}$ Maliki's confrontation with Sunni politicians, such as Tarek Hashemi, Rafi al-Issawi and Saleh al-Mutlak, who accepted the political process but aimed to curb Maliki's power and sought greater Sunni incorporation, diminished the remaining Iraqi government channels to the Sunni community.

The first impact of the Arab uprisings, and the geopolitical rivalries they engendered, was to exacerbate Iraq's sectarian and ethnic divisions. In March 2011, the 
tide of the Arab uprisings reached Syria and assumed a sectarian dimension by 2012 . The rise of sectarian discourse in the region and the emergence of ostensibly sectarian camps, with Iran, the Syrian regime, and Hizbullah on the one hand, and Turkey, Qatar, and Saudi Arabia on the other hand came to directly affect Iraq, which became an arena for regional rivalries. Saudi Arabia and Turkey capitalised on Sunni disenchantment within Iraq to weaken the Shi'a-dominated regime and to curb Iran's influence in the region. This aggravated Shi'a worries and led al-Maliki's government to transform its previous enmity against Assad into support for his survival; Shi'as feared that the coming of a "Sunni" regime in Syria would empower Iraqi Sunnis and weaken, if not topple, the newly established Shi'a-dominated regime in Iraq. The Iraqi government's support of Assad heightened the domestic Sunni-Shi'a divisions. Many Iraqi Sunnis supported the Syrian rebellion against Assad, connecting their own grievances to that of their Syrian coreligionists. ${ }^{46}$ By 2012, Iraqi Sunnis of Anbar and other Sunni regions began protests calling for an end to 'Sunni marginalization', release of detainees, and for Maliki to step down. Dismissing the uprisings as an 'external conspiracy', Maliki failed to accommodate the demands of the protestors who began to garner support from Sunni MPs and politicians. ${ }^{47}$

Exploiting the Sunni uprising and regime erosion in Sunni areas, ISIS and former Baathists began to occupy areas of western and northern Iraq. In early June 2014, Mosul fell to ISIS and by the end of the month, the al-Qaida breakaway declared its 'Islamic State' on a wide swath of territories ranging from the east of Aleppo in Syria to the Sunni-majority regions, including Anbar, Ninenevah, and Mosul in Iraq. ${ }^{48}$. The quick collapse of the Iraqi army in these Sunni areas exposed its weak legitimacy. ${ }^{49}$ Indicative of the sectarian framing encouraged by rival regional powers, when Mosul fell to ISIS, Saudi Arabia considered it to be a 'revolution' by Sunnis who were frustrated by Maliki's rule..$^{50}$

The occupation of most of the Sunni areas by the Islamic State led Mazuud Barazani to exploit the Iraqi army's weakness to occupy the oil-rich and contested territory of Kirkuk. Barazani then announced that the Iraqi political process had failed and conditions for Kurdish statehood had emerged.51 By August of 2014, the statebuilding process in Iraq and the impact of the Arab uprisings did not only besiege democratic consolidation, as will be argued in the conclusion, but also threatened the disintegration of Iraq as a state. 
Compared to Iraq, the Arab uprisings had a more damaging effect on Syria. The coming of Bashar Assad to power in 2000 reflected a continuation of the regime his father had established in Syria. Despite the favourable external opportunities (after the 2006 Lebanon war, which increased regime legitimacy; the Saudi opening to Syria in 2008; improved relations with Turkey and France), Bashar al-Assad failed to create a more politically inclusive regime. This failure made his regime, and in consequence Syria's territorial integrity, vulnerable to the Arab uprisings, which reached Syria in March 2011. Within a few weeks, the realm of politics, which was concentrated in a few hands, and which contained and repressed any attempts to promote alternative political visions, opened widely for numerous political actors that rose to challenge Assad's rule. In this contentious episode, we observe both a continuation of and innovation in regimesociety contention.

Initially, Syrian protestors consciously avoided any sectarian or ethnic slogans that might alienate Syria's minorities and that the regime could use to delegitimise the opposition. The peaceful protesters called for 'reform' and advanced a democratic and pluralistic vision, thus challenging Assad's monopoly over the national narrative. ${ }^{2}$ But the regime's strategy to prevent any Midan al-Tahrir-like contentious performance led it to overreact violently. Beyond the use of violence, Assad, relying on the support of state employees, some segments of the urban middle classes, his own Alawi base, and the Syrian crony capitalists that had benefited from privatisation schemes, ${ }^{53}$ staged counter political rallies in most of Syria's cities; he called for a national dialogue; and drafted and then held a referendum on a new constitution, ending the Baath's 'legal' monopoly over the political system. ${ }^{54}$ Whilst these regime adaptations could have contributed to political reform, they, however, failed to attract support from the Syrian opposition, the Syrian National Council (SNC), most of which was in exile and expected a swift fall of the regime. ${ }^{55}$

Assad's survival, however, and the absence of a political agreement on transition gave rise to an armed struggle, transforming Syria into a collapsed state marred by a civil war. In a span of two years (2011-2013) Syria turned from an influential regional actor into a battlefield for geopolitical rivalries. In the eyes of the opposition, political protest, on its own, had revealed its limits ${ }^{56}$. However, despite many defections, the army and the Republican Guard remained largely intact. Due to fear of regime's violence or because of the absence of a clear alternative, Syria's main cities (Damascus and 
Aleppo) did not instantly rise against the regime. Whilst the Arab uprisings had had a demonstration effect, sectarianism in Iraq since 2003 and the bloody fall of Qaddafi in Libya, formed counter demonstration effects that restrained revolt in Syria's big cities. Despite the varying origins of the rebellion-from the rise of Salafism in Dera, to opposition against religious restrictions in Banyas, to a revolt against the Alawi shabbiha in Latakia-it was concentrated in the periphery, where state services and control has weakened, before moving to Sunni hotbeds in Hama and Deir el-Zur. ${ }^{57}$ Assad's military strategy aimed to concentrate efforts on the main cities in order to preserve the strategic link between Damascus-Homs-Latakia, but this came at the expense of leaving peripheral areas to the control of rebel groups.

With state weakening and regime loss of territory to the opposition, initially to the Free Syrian Army (FSA) of military defectors, Islamist jihadist groups began to see an opportunity to establish a foothold in Syria. ${ }^{58}$ The rise of jihadist groups, such as Jabhat al-Nusra and ISIS, aggravated the sectarian divide which the civil war had activated. The regime's Alawite core, memories of the Hama massacre in 1982, and regime's alliance with Shi'a Iran and Lebanon's Hizbullah fostered sectarian framings and mobilisation. The erosion of secular Arab nationalist ideology in the state-building process, and Bashar Assad's failure to articulate a new ideology since 200059, left a vacuum that was filled by sectarian and tribal identities. But despite this, in its discourse and through its media outlets, the regime continued to promote a national narrative, aiming to demobilise sectarian divisions and framing the conflict as one between the "state", which represents plurality, stability and sovereignty, and the "terrorists", who are agents of external powers wanting the disintegration of the Syrian state $^{60}$. The failure of the opposition to unite ranks, made radical Islamism, manifested in the jihadist ISIS and Jabhat al-Nusra, the main political alternative to Assad. Fearing for their survival should the Islamists win, most of Syria's minorities and many of urban Sunnis backed the regime.

What exacerbated the Syrian conflict and shaped its development were regional geopolitical rivalries. The opportunity that the uprisings offered to unseat Assad led many of his regional foes, Saudi Arabia, Turkey and Qatar, to capitalise on domestic opposition to achieve their strategic goals. For Saudi Arabia, toppling Assad and installing a friendly regime would curtail Iranian expansion, weaken the 'Resistance Axis', and potentially isolate Iran and Hizbullah. For Turkey and Qatar, the rise of a 
potentially Islamist (Muslim Brotherhood) regime in Syria would not only contain Iran and isolate Saudi Arabia, but would also likely facilitate Turkey's bid to establish economic and political hegemony in the Arab region in alliance with moderate Islamist movements. This strategy aimed to fill the vacuum left by the diminishing U.S. Middle East role under the Obama administration ${ }^{61}$. For Iran, Hizbullah, and, as mentioned above, the Iraqi regime, a fall of Assad would be a strategic loss and a threat to Shi'a influence in the region. Lebanon's Hizbullah feared that Assad's fall would diminish the movement's strategic depth in its conflict with Israel. ${ }^{62}$

The rivalries of these geopolitical camps began to directly affect the civil war in Syria. Each camp began to channel money, arms, and men to its domestic allies in Syria. On the one hand, these external infiltrations contributed to the further erosion of the Syrian state; but on the other hand, Hizbullah's direct military intervention and support from Iran and Russia kept the regime intact. Geopolitical rivalry pitting Saudi Arabia against Qatar and Turkey weakened and further divided the Syrian opposition, contributing to Assad's survival and to the rise of the more robust Jihadist groups. The control of the rebel areas by Jihadists provided them with the opportunity to apply their political vision. The execution of rivals, the violent application of Islam, and the sectarian attitude of these groups augmented the feeling of fear among Syria's minorities and gave credence to the regime's proposition that the most viable alternative to its rule would be the jihadists.

By the end of 2013, the Syrian war had caused more than 100,000 deaths, two million refugees, ${ }^{63}$ and the disintegration of the country. In June 2014, more than half a century after the Baath Party found roots in Syria and Iraq, a new ideological movement represented in ISIS announced its "Caliphate", straddling the Sykes-Picot political boundaries, and dominated over most of eastern Syrian and western Iraq. ${ }^{64}$

\section{Conclusion: Prospects and Obstacles to Democratisation in Iraq and Syria}

The Arab uprisings was an episode of contentious politics that challenged the existing political order in Iraq and Syria and formed an opportunity to renegotiate the basis of political rule in each of the two cases. However, due to the coercive state-building process in Iraq and Syria, their heterogeneous social composition, and geo-political locations, the Arab uprisings led to state disintegration in both countries. Whilst the challenge to the state boundaries represented by ISIS may not endure, largely due to the 
socio-political resistance this movement faces in Arab societies and to the resistance of the international and regional systems to a revision of state boundaries, both countries face long term challenges to consolidate (Iraq) or reconstruct (Syria) political systems.

Whilst the politicisation of sectarian and ethnic identities in Iraq and Syria appears to cause state disintegration and civil wars, this politicisation, under the right conditions, might contribute to democratisation. Iraq has already made an important transition towards political pluralism, accepting the presence of various sectarian and ethnic grievances, visions, and interests. In ratifying a constitution, holding elections, allowing for a pluralist press, and designing state institutions, Iraq had begun to translate political pluralism into political institutions. However, the US occupation until 2011, Sunni dissatisfaction, and sectarian and geopolitical rivalries, especially under the rule of al-Maliki, stalled the attempt to build a consociational democracy. As a divided state with a fragile democracy, Iraq's political development and stability, like that of Lebanon, largely depends on its regional setting. A favourable and less polarised regional setting might contribute to stabilising Iraq and furthering its democratic experiment-and vice versa. To find a solution to the crisis, the US called for a 'national unity' government, indicating the need to reincorporate the Sunnis. When Iran and the Iraqi Shi'a supreme leader Ayatollah Sistani made similar calls, the room for al-Maliki to seek a third term diminished, paving the ground for the appointment of Haidar al-Abadi. Regional fears of ISIS expansion, especially into Irbil or Baghdad, led regional rivals to converge in calling for national unity in Iraq. Saudi Arabia was among the first to recognise the newly-appointed Shi'a Prime Minister65.

Whilst the incorporation of various communities in a consociational system is a prerequisite for its success, this system, as the experience of Lebanon suggests, generates its own problems. The participation of different actors in 'national unity' governments, which usually includes the main representatives of each community, leaves little room for an effective political opposition, and, hence, accountability. The apportionment of state positions-in the judiciary, security and intelligence forces, central banks-among the ruling multi-communal coalition weakens these institutions since most of the main appointments are political patronage meant to serve the political power position of rival politicians within the state apparatus. These appointments increase the vulnerability of political institutions to political rivalries and hinder their capacity to become effective regulators of the political system. 
Unlike Iraq, Syria still has to make the transition to political pluralism. The inability of the opposition to topple Assad and of Assad to reproduce his former domination is lengthening the war. Geopolitical rivalries over Syria are directly contributing the continuation of the struggle. Syria takes a central place in the strategies of the vying camps in the region since developments there are key to regional shifts in the balance of power. Whilst prospects for democratization in Syria are remote, an external agreement that would preserve the minimum interests of regional (Saudi Arabia and Iran) and international (USA and Russia) actors could still trigger a political process that would facilitate internal political change. Such a framework, similar to the Taif Accord, which brought the Lebanese civil war to an end, would widen the political scope to include various political forces. In their discourses, both the regime and the opposition have avoided explicitly proposing a consociational (sectarian) arrangement, preferring to present a 'national' platform. However, any political opening and dialogue is very likely to juxtapose heterogeneous Syrian communities against on another; beyond the Syrian national identity that binds all groups, and in the absence of ideological divides (with the possible exception of Islamism-non-Islamism) among different Syrian groups, sectarianism and--in the case of Syria's Kurds--ethnicity are very like to form the new boundaries of a future political system. Minority groups, including the one represented by the regime, would require assurances that a future political system would guarantee them influence at the centre of decision-making, in coercive agencies of the state, and in parliament.

Whilst state formation and crystallisation long preceded democratisation in Europe, in countries like Iraq and Syria, and for that matter Lebanon, Libya, Yemen, these two processes are converging. Iraq and Syria are finding that to reconstruct (and avoid the collapse of) their states they will need to open the political arena to various communal and political actors, triggering a process of democratisation. Successful state formation will mean democratisation. But this process is, and will be, burdened by major challenges, not least the geopolitical rivalries; by political Islam, especially extremist versions, such as ISIS, that challenge democracy as a political system; by transnational sectarianism that is inflaming divided societies; and by the sectarian/ethnic apportionment that enervate institutions, decrease accountability, and facilitate corruption in consociational versions of democracy. 


\section{Notes}

${ }^{1}$ For a critical overview, see Hinnebusch, Authoritarian persistence, 373-395.

2 For examples see Salame, "Where are the Democrats?"; Waterbury, "Democracy Without Democrats?"; Korany et.al., Political Liberalization and Democratization in the Arab World.

${ }^{3}$ Schlumberger, "Arab Authoritarianism," 6, (emphasis in original); Bellin, "The Robustness of Authoritarianism," 148.

${ }^{4}$ Gause III, "Why Middle East Studies Missed the Arab Spring," 81-90.

5 Valbjorn, "Upgrading Post-democratization Studies," 29; Brynen et.al. Beyond the Arab Spring, 1.

${ }^{6}$ Anderson, "Searching Where the Light Shines," 209

${ }^{7}$ Schlumberger, "Arab Authoritarianism", 7-8.

8 Tripp, The Power and the People, 4

${ }^{9}$ Saouli, The Arab State.

10 Valbjorn, "Upgrading Post-democratization Studies," 31; see also Anderson, "Searching Where the Light Shines," 210; Cavatorta and Durac, Civil Society and Democratization, 9; Hinnebusch, Toward a Historical Sociology, 214; Saouli, The Arab State, 3

11 See also, Teti, Beyond Lies the Wub, 18-20; Valbjorn, "Upgrading Postdemocratization"

12 Anderson, "Searching Where the Light Shines", 199

13 Compare with Raymond Hinnebusch, Toward a Historical Sociology, 201-216.

${ }^{14}$ As Hinnebusch (2001:60) observes of Syria 'when the legitimacy of party institutions and the holders of coercive power were confronted in the starkest fashion, the latter triumphed'.

15 Tilly, Coercion, Capital, and European States

16 A regime is 'an alliance of dominant ideological, economical, and military power actors coordinated by the rulers of the state', Mann, The Sources of Social Power, 18

17 Weber, Politics as a Vocation, 2

18 Hinnebusch, Toward a Historical Sociology,

${ }^{19}$ Saouli, The Arab State,

20 McAdam, Tarrow, and Tilly, Dynamics of Contention, 5.

${ }^{21}$ Snow and Benford quoted in Snow, 'Framing Processes, Ideology, and Discursive Fields", 384

22 Saouli, Performing the Egyptian Revolution.

23 McAdam, Tarrow, Tilly, Dynamics of Contention, 43.

24 Tilly, Identities, boundaries, and social ties, 216.

25 For an illustration of this point, see the documentary produced by Vice News on ISIS's state-making processes in territories occupied in Iraq and Syria https://www.youtube.com/watch?v=AUjHb4C7b94 , accessed on 3 October 2014.

${ }^{26}$ For an alternative argument on the emergence of consolidated states in Syria and Iraq with 'strong state institutions' that 'aimed at securing and enhancing national sovereignty', see Mufti, Sovereign creations, 9.

${ }^{27}$ For Syria, see Van Dam, The Struggle for Power in Syria, 34-75. For Iraq, see Saouli, The Arab State, pp.109-124.

${ }^{28}$ Hinnebusch, Syria: Revolution from Above, 115-138.

${ }^{29}$ Van Dam, The Struggle, p. 91.

${ }^{30}$ For a detailed analysis of this process, see Saouli, The Arab State, pp.118-120 
31 Van Dam, The Struggle for Power in Syria, pp.48- 74, 70.

${ }^{32}$ For the rise of Shi'a political consciousness, emergence of Shi'a political organisations, and regime-Shi'a contention, see Jabr, The Shi'ite Movement in Iraq.

33 On the 1991 Shi'a uprising see Ibid., 269-71. On regime-Kurdish relations see, Gunter, The Kurds of Iraq.

34 Van Dam, The Struggle for Power in Syria, pp. 105-117

35 Ibid., p. 91

${ }^{36}$ Hinnebusch, "Syria: from 'authoritarian upgrading' to revolution?,"

37 For a theoretical and empirical base for this argument, see Saouli, The Arab State, 4965.

38 During the crisis, Sadat highlighted Assad's regime as 'firstly Alawi, secondly Ba'thist, and thirdly Syrian', contributing to the weakening of his regime. Sadat quoted in Van Dam, The Struggle for Power, 73.

${ }^{39}$ For the uprising and the activation of sectarian boundaries in Iraq, see Haddad, Sectarianism in Iraq, 65-86.

40 Saouli, The Arab State, pp. 128-133.

41 On Sunni perception of the new Iraq, see Fanar, Sectarianism in Iraq, 143-178.

42 Saouli, The Arab State, 130-132.

43 On the rise of Sunni resistance, see Dodge, Iraq, 44, 57, 89-90.

44 Ibid.193-4.

45 Ibid.147-180.

${ }^{46}$ For Iraqi responses to the Syrian uprisings, see Saouli, "The Foreign Policy of Iraq and Lebanon".

47 http://www.theguardian.com/world/2012/dec/26/iraq-protests-tension-sunni-shia (Accessed 10 August 2014)

48 http://www.theguardian.com/world/2014/jun/10/iraq-sunni-insurgents-islamicmilitants-seize-control-mosul (Accessed 13 August 2014).

49 http://www.bbc.co.uk/news/world-middle-east-28082962 (Accessed 13 August 2014)

50

http://www.reuters.com/article/2014/06/16/us-iraq-security-qataridUSKBN0ER1JF20140616 (Accessed on 13 August 2014|).

51 http://www.nytimes.com/2014/06/13/world/middleeast/iraq.html? r=0 (Accessed 13 August 2014).

52 Ismail, The Syrian Uprising, 538-549; see also, Tripp, The Power and The People, 55-58

${ }^{53}$ Hinnebusch, "Syria: from 'authoritarian upgrading' to revolution?," 98-100.

$54 \mathrm{http://www.bbc.co.uk/news/world-middle-east-12892870} \mathrm{(Accessed} 15$ August 2014); $\quad$ http://www.theguardian.com/world/2012/feb/26/syria-referendumconstitution-homs-shelling (Accessed 15 August 2014)

55 Hokayem, Syria's Uprising , 71-2.

56 International Crisis Group,"Syria's Metastasising Conflicts", 143.

57 Hinnebusch, Syria: from 'authoritarian upgrading', 107

58 On the Islamist factions of the opposition, see, Hokayem, Syria's Uprising, 93-102.

${ }^{59}$ Hinnebusch, Syria: from 'authoritarian upgrading', p. 99.

${ }^{60}$ For example, the Syrian regime continues to pay the salaries of state employees in territories occupied by the opposition 'maintaining an image of the state', on this point see Firas Khalife, 'Life continues in Damascus...with an eye on the "Coalition" war 
[Dimashq tamdee bi hayatiha...wa iynaha ala harb "al-tahaluf", http://assafir.com/Article/5/374920, accessed on 29 October 2014.

${ }^{61}$ Hokayem, Syria's Uprising, pp. 105-148

${ }^{62}$ For Hizbullah's perception of the uprising in Syria, see Saouli, "Hizbullah, Hamas, and the Arab Uprisings, 37-44.

63 The Guardian (2013), "Humanitarian Crisis: Syria's Nightmare", in The Guardian, 4 September, http://www.theguardian.com/commentisfree/2013/sep/04/humanitariancrisis-syria-nightmare-editorial (accessed on 19 October 2013).

$64 \mathrm{http}: / /$ www.bbc.co.uk/news/world-middle-east-28082962 (Accessed 13 August 2014)

65 http://www.theguardian.com/world/2014/aug/14/iraqi-prime-minister-malikistep-aside-abadi (Accessed on 15 August 2014|).

\section{Bibliography}

Anderson, Lisa. "Searching Where the Light Shines: Studying Democratization in the Middle East." Annual Review of Political Science, 9, no.1 (2006): 189-214.

Bellin, Eva. "The Robustness of Authoritarianism in the Middle East: Exceptionalism in Comparative Perspective." Comparative Politics 36, no.2 (2004): 139-157.

Brynen, Rex, Pete W Moore, Bassel F. Salloukh and Marie-Joelle Zahar, eds. Beyond the Arab Spring: Authoritarianism \& Democratization in the Arab World. Boulder: Lynne Rienner, 2013.

Brynen, Rex, Bahgat Korany and Paul Noble eds. Political Liberalization and Democratization in the Arab World: Theoretical Perspectives (Boulder, Colorado: Lynne Rienner Publishers, 1995)

Cavatorta, Francesco and Vincent Durac, Civil Society and Democratization in the Arab World: The dynamics of Activism. London: Routledge, 2010.

Dodge, Toby. Iraq: From war to a new authoritarianism. Abdington: Routledge, 2012.

Gause III, Gregory F. "Why Middle East Studies Missed the Arab Spring." Foreign Affairs, 90, no.4 (2011): 81-90.

Gunter, Michael M. The Kurds of Iraq: tragedy and hope. New York: St. Martin's Press,1992.

Haddad, Fanar. Sectarianism in Iraq: Antagonistic Visions of Unity. London: Hurst and Company, 2011.

Hokayem, Emile. Syria's Uprising and the Fracturing of the Levant. Abingdon, Routledge: 2013), 
Hinnebusch, Raymond. "Syria: from 'authoritarian upgrading' to revolution?" International Affairs, Vol.88, No.1 (2012), pp. 95-113.

. "Toward a Historical Sociology of State Formation in the Middle East." Middle East Critique, Vol.19, No.3 (2010): 201-216.

"Authoritarian persistence, democratization theory and the Middle East." Democratization 13, no.3 (2006): 373-395.

Syria: Revolution from Above. London: Routledge, 2001.

Ismail, Salwa. 'The Syrian Uprising: Imagining and Performing the Nation.' Studies in Ethnicity and Nationalism 11, no. 3 (2011): 538-549.

International Crisis Group. Syria's Metastasising Conflicts, no. 143. Brussels: International Crisis Group, 2013.

Jabr. Faleh A. The Shi'ite Movement in Iraq. London: Saqi, 2003.

Mann, Michael. The Sources of Social Power. Cambridge: Cambridge University Press, 1993.

McAdam, Dough, Sidney Tarrow, and Charles Tilly, Dynamics of Contention. Cambridge: Cambridge University Press, 2001.

Mufti, Malik. Sovereign creations : pan-Arabism and political order in Syria and Iraq. New York and London: Cornell University Press, 1996.

Salame, Ghassan, "Introduction: Where are the Democrats?," in Ghassan Salame ed. Democracy without Democrats?: The Renewal of Politics in the Muslim World. New York: I.B. Tauris, 1994: 1-22.

Saouli, Adham. "Performing the Egyptian Revolution: Origins of collective restraint action in the Midan." Political Studies, doi: 10.1111/1467-9248.12135

The Arab State: Dilemmas of Late Formation. London: Routledge, 2014

"The Foreign Policy of Iraq and Lebanon" in Raymond Hinnebusch and Anoushiravan Ehteshami (eds) The Foreign Policies of Middle East States (Lynne Rienner: Boulder, 2014)

.Hizbullah, Hamas, and the Arab Uprisings: Structures, Threats, and Opportunities." Orient, 54, no. 2 (2013): 37-44.

Schlumberger, Oliver. "Arab Authoritarianism: Debating the dynamics and durability of nondemocratic Regimes," in Oliver Schlumberger (ed.) Debating Arab Authoritarianism: 
Dynamics and durability in Nondemocratic Regimes. California: Stanford University Press, 2007.

Snow, David A. "Framing Processes, Ideology, and Discursive Fields," in David A. Snow, Sarah A. Soule, and Haspeter Kriesi (eds), The Blackwell Companion to Social Movements. Victoria, Australia: Blackwell Publishing, 2004.

Teti, Andrea. "Beyond Lies the Wub: The Challenges of (Post) Democratization." Middle East Critique 21, no.1 (2012): 5-24.

Tilly, Charles. Identities, boundaries, and social ties. Boulder, Colorado: Paradigm, 2005. Coercion, Capital, and European States, AD 990-1990. Oxford: Basil Blackwell

Tripp, Charles. The Power and the People: Paths of Resistance in the Middle East. Cambridge: University of Cambridge Press, 2013.

Van Dam, Nicholas. The Struggle for Power in Syria: Politics and Society Under Asad and the Ba'th Party. London: I.B. Tauris, 2011.

Valbjorn, Morten. "Upgrading Post-democratization Studies", Middle East Critique 21, no.1 (2012): 25-35.

Waterbury, John. "Democracy Without Democrats?: the potential for political liberalization in the Middle East," in Ghassan Salame ed. Democracy without Democrats?: The Renewal of Politics in the Muslim World. New York: I.B. Tauris, 1994: 23-47. 